\title{
An Assessment of Reliability and Validity of the Attitudinal and Behavioural Typology of Customer Loyalty in a Developing Country: Evidence from Zimbabwe
}

\section{Charles Makanyeza}

\author{
School of Management, Information Technology \& Governance, \\ University of KwaZulu-Natal, Westville, Durban, South Africa \\ Email: cmakanyeza@yahoo.co.uk or 212561327@stu.ukzn.ac.za
}

\author{
Doi:10.5901/mjss.2015.v6n1s1p310
}

\begin{abstract}
Considerable attention has been given to the construct of customer loyalty in marketing practice and research. However, this construct remains relatively unexplored. Its measurement has generated substantial debate and confusion. The introduction of the attitudinal and behavioural approach to the measurement of customer loyalty has managed to bring marketing minds together. And yet, there is a dearth of empirical evidence on the reliability and validity of this approach. This study, therefore, sought to assess the reliability and validity of the attitudinal and behavioural typology of customer loyalty in Zimbabwe, a developing country. The study took a cross-section of 400 consumers in two major cities (Harare and Bulawayo) in Zimbabwe. An interviewer-administered questionnaire was used to collect data. Consumers were randomly intercepted while shopping in major supermarkets. A measurement model was developed and validated using structural equation modelling in AMOS 21. The study established that the attitudinal and behavioural typology is a reliable and valid measure of customer loyalty. Thus, the attitudinal and behavioural typology of customer loyalty is applicable in developing countries such as Zimbabwe. Marketing practitioners and researchers in developing countries are, therefore, recommended to consider both attitudinal and behavioural components when planning customer loyalty programmes and conducting consumer research.
\end{abstract}

Keywords: Consumer behaviour, Customer loyalty, Dimensions of loyalty, Typology of loyalty, Measurement of loyalty

\section{Introduction}

As world trade barriers weakened in recent decades, there has been an increased movement of products across national boundaries. Consumers have been spoilt for choice on a wide range of products from both local and foreign markets. This has intensified competition the world over (Teo, Mohamad \& Ramayah, 2011; Ranjbarian, Rojuee \& Mirzaei, 2010; Saffu \& Walker, 2006). In this globalised business environment, the survival of firms has largely been dependent on the attraction and retention of loyal customers. Thus, the customer has become the central focus for most successful businesses (Boohene \& Agyapong, 2011; Beerli, Martín \& Quintana, 2004). Similarly, Kotler, Keller, Brady, Goodman and Hansen (2009), Yang and Peterson (2004) and Knox and Denison (2000) concur that successful businesses have placed customer loyalty at the heart of their marketing strategy.

Customer loyalty is described by Oliver (1999) as an intense commitment that drives customers to rebuy or repatronise a preferred product or service consistently in the future. This results in repeated same-brand or same brandset purchasing irrespective of situational influences and marketing efforts that can cause switching behaviour. Thus, loyal customers engage in repeat purchasing, leading to increased sales volume and profit (Kotler et al., 2009; Lewis \& Soureli, 2006; Caruana, 2002; Kandampully \& Suhartanto, 2000). Likewise, Beerli et al. (2004) and Gefen (2002) agree that customer loyalty increases the value of business and it reduces costs associated with attracting new customers. Apart from recommending the firm's products to other customers, loyal customers are prepared to pay premiums for the company's offerings (Lewis \& Soureli, 2006; East, Gendall, Hammond \& Lomax, 2005; Delgado-Ballester \& MunueraAlemán, 2001; Knox \& Denison, 2000; Rossat, Larsen, Ruta \& Wawrzynosek, 1999). Customer loyalty also assures the firm of more and guaranteed income and market share, increased employee morale and productivity, consumer price indifference, positive word-of-mouth communication, cross sales, referrals and endorsements (Lewis \& Soureli, 2006; Kandampully \& Suhartanto, 2000). Customers with true loyalty give the firm some leverage and ample time to respond to competitive moves because they resist competitive manoeuvres (Lewis \& Soureli, 2006; Knox \& Denison, 2000).

As a construct, customer loyalty has been given much attention in the field of marketing. However, the measurement of customer loyalty has generated a lot of confusion and debate (Lewis \& Soureli, 2006; Söderlund, 2006; Yu \& Dean, 2001). In this regard, Yu and Dean (2001) submit that the construct of customer loyalty is complex while 
McMullan and Gilmore (2003) noted that, despite more attention being given to the development of customer loyalty as the focal point of marketing strategy, this construct has remained relatively unexplored. The extant literature has shown a general consensus among marketing scholars (Lewis \& Soureli, 2006; East et al., 2005; Assael, 2004; Garland \& Gendall, 2004; Yang \& Peterson, 2004; Yi \& Jeon, 2003; Baloglu, 2002; Kandampully \& Suhartanto, 2000; Oliver, 1999; Dick \& Basu, 1994) that customer loyalty is a two-dimensional construct that comprises attitude and behaviour. The need to have an effective measure of customer loyalty is immense due to the strategic nature of this construct in marketing. However, there is a dearth of research in the public domain that has empirically validated the attitudinal and behavioural typology of loyalty. To worsen matters, most studies on customer loyalty have been concentrated in developed nations. This makes the application of the findings to developing countries somewhat questionable. Calls have also been made for marketing practitioners and researchers to be cautious when using scales developed in other countries (Pentz, Terblanche \& Boshoff, 2013; Douglas \& Nijssen, 2003).

This study, therefore, assesses the reliability and validity of the attitudinal and behavioural typology of customer loyalty towards imported poultry meat products in Zimbabwe, a developing country. The choice of the country and imported poultry meat product category was motivated by the fact that Zimbabwe has witnessed an increased flow of imported poultry products mainly from Brazil, South Africa and USA since 2009 after the adoption of multi-currencies. Poultry imports have intensified competition in the country's poultry sector (Irvine's, 2012). It is hoped that a study of this nature can be useful to marketing practitioners and researchers as they seek to have a sound understanding of the construct of customer loyalty, which has been alluded to in literature as a key strategic consideration in marketing. More so, assessing the reliability and validity of customer loyalty in a developing country set-up would enrich the growing knowledge base of customer loyalty.

\section{Literature Review}

\subsection{Definition and scope of customer loyalty}

The construct of loyalty is deeply rooted in the theory of consumer behaviour and it has evolved over the years (Boohene \& Agyapong, 2011; Caruana, 2002). Since the 1950s, customer loyalty has received much attention in both academia and business (Knox \& Denison, 2000). In its infancy, loyalty focused on brand loyalty with regard to tangible products. With the passage of time, the focus of loyalty shifted to include other forms such as vendor or store loyalty (Caruana, 2002). Likewise, many authors agree that consumers exhibit loyalty towards objects such as brands, stores, services and activities (Boohene \& Agyapong 2011; Knox \& Denison, 2000). Concurring to this, East et al. (2005) and East, Sinclair and Gendall (2000) posit that loyalty manifests through different propensities-loyalty can be to a brand, store or service. Similarly, Dick and Basu (1994) noted that although the bulk of marketing research has focussed on loyalty towards packaged goods (brand loyalty); there are other forms of loyalty, namely vendor loyalty (concerned with industrial goods), service loyalty (concerned with services) and store loyalty (concerned with retail shops). However, Boohene and Agyapong (2011) are of the view that the term 'customer loyalty' is more appropriate than 'brand loyalty' because loyalty is not inherent in brands or products but it is inherent in people.

There are as many definitions of customer loyalty as there are scholars. In this regard, there is no universally agreed upon definition of this concept (Boohene \& Agyapong, 2011; Schiffman \& Kanuk, 2004; Oliver, 1999; Dick \& Basu, 1994). Customer loyalty is defined by Beerli et al. (2004:254) as "repeat purchasing frequency or relative volume of same-brand purchasing". A similar definition in Yi and Jeon (2003:231) refers to customer loyalty as "repeated purchases of particular products or services during a certain period". These definitions of customer loyalty, like many others, have been criticised because they seem to focus on what the consumer does i.e. behavioural loyalty, paying little attention to the psychological meaning of customer loyalty (Beerli et al., 2004; Schiffman \& Kanuk, 2004). And yet, behavioural definitions-such as frequency of purchase or proportion of total purchases-of consumer loyalty lack precision because they do not distinguish between the 'real' brand loyal buyer who is intentionally faithful and the spurious brand loyal consumer who repeats a brand purchase simply because it is the only one available at the store (Assael, 2004; Schiffman \& Kanuk, 2004). Likewise, considering only the behavioural dimension of loyalty can be misleading in the sense that customers may buy products as a result of different influences such as happenstance purchasing as well as convenience purchasing. More so, infrequent purchasing may mask loyalty if consumers are loyal to many brands. Thus, loyalty is much more than repeat purchase. It extends to include attitude which manifests through commitment (Beerli et al., 2004). Similarly, Caruana (2002) observes that early research focused on behavioural loyalty, with little attention given to psychological aspects of loyalty. Developments in the study of loyalty witnessed the focus of loyalty expanding to include the attitudinal element. In this regard, customer loyalty has been described as "the strength of the relationship between 
an individual's relative attitude and their repeat patronage" (Dick \& Basu, 1994:99). Thus, attitude is relative because there are alternative offerings or brands toward which consumers have attitudes (East et al. 2005). More so Oliver (1999:36) refers to customer loyalty as:-

A deeply held commitment to rebuy or repatronise a preferred product/service consistently in the future, thereby causing repetitive same-brand or same brand-set purchasing despite situational influences and marketing efforts having the potential to cause switching behaviour.

Thus, loyalty may represent a commitment to a brand that may not be reflected by just measuring continuous behaviour. The very term 'loyalty' implies a commitment rather than just repetitive behaviour; which suggests that there is a need to consider both cognitive as well as behavioural elements when defining customer loyalty (Assael, 2004; Schiffman \& Kanuk, 2004; Oliver, 1999).

Considering that loyalty is a product of favourable propensities-which are behavioural or attitudinal—toward a particular object (East et al., 2005; East et al., 2000), marketers should distinguish between true loyalty customers and those that appear to be loyal (Baloglu, 2002). Based on the cross-classification of attitudinal and behavioural loyalty, Dick and Basu identified four levels of loyalty, namely true loyalty (high loyalty), latent loyalty, spurious loyalty and low loyalty (no loyalty) as illustrated in Figure 1.

Customers with true loyalty have strong attitudes and high repeat purchase behaviour toward a product or brand. In most cases these customers purchase a particular brand or patronise a particular service provider. They are not easily swayed by competitive moves (Garland \& Gendall, 2004; Baloglu, 2002; Dick \& Basu, 1994). In true loyalty, a conscious decision to continue purchasing a particular product must be accompanied by the favourable attitude and commitment toward that product (Boohene \& Agyapong, 2011).

Latent loyalty is characterised by strong attitudinal commitment and low purchase behaviour. Although they have favourable attitudes toward the brand, consumers with latent loyalty may not have enough financial resources to increase purchase of a product or patronage of a store (Garland \& Gendall, 2004; Baloglu, 2002; Dick \& Basu, 1994).

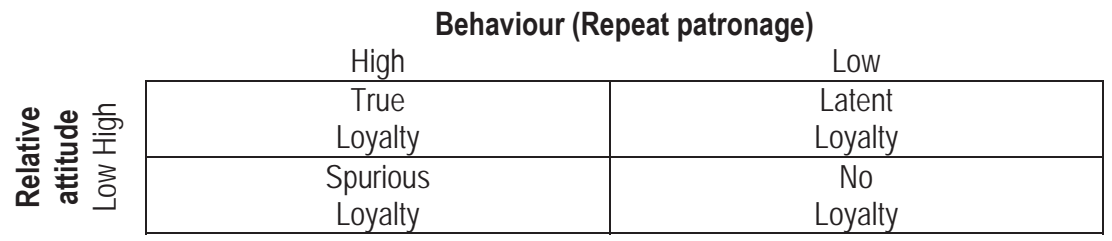

Figure 1. Four levels of customer loyalty

Source: Adapted from Garland and Gendall (2004); Schiffman and Kanuk (2004); Baloglu (2002); Dick and Basu (1994)

Customers with spurious loyalty are not emotionally attached to the brand even though they may frequently purchase it. Their purchase may be motivated by such factors as incentives in the purchase, habits, lack of alternatives, individual circumstances and situational cues (Schiffman \& Kanuk, 2004; Baloglu, 2002; Dick \& Basu, 1994). Situational cues include packaging, brand familiarity, shelf positioning, or special prices. In this regard, Schiffman and Kanuk (2004) suggest that consumers with spurious loyalty can continue to purchase products or brands even though they may not like them. Likewise, Assael (2004) submits that an uncommitted customer may continue shopping in a particular store because he/she does not have sufficient time and it is easier to shop in one place. This reflects inertia rather than true loyalty. Spurious loyal customers are described by Baloglu (2002) as volatile. As such they are targeted by competitors.

Customers with low loyalty have no loyalty at all. Their attitudinal attachment is low. They also do not purchase the brand repeatedly. Just like in the spurious loyal categories, low loyalty customers are volatile and thus targeted by competitors (Garland \& Gendall, 2004; Baloglu, 2002; Dick \& Basu, 1994).

\subsection{Importance of customer loyalty}

As relationship marketing gained importance in recent years, much attention has been directed at customer loyalty (Beerli et al., 2004). In support of this, Boohene and Agyapong (2011) and Knox and Denison (2000) concur that the construct of customer loyalty has received much attention in both academia and business since the 1950s. It has been considered to be of utmost importance in the consumer marketing environment for over the years (Yang \& Peterson, 2004). In this 
regard, Kotler et al. (2009) stress the importance of customer loyalty by observing that many companies are now investing their significant financial resources in building customer loyalty. The major reason behind this is that customer loyalty has been central to the development of effective marketing strategy. Thus, the management of customer loyalty has presented a huge task to the marketer in the current environment that is laden with increasing global competition (Dick \& Basu, 1994).

Customer loyalty increases the firm's performance, particularly profitability. It is generally agreed that there is a positive relationship between customer loyalty and business performance i.e. customer loyalty increases the value of business and it reduces costs associated with attracting new customers (Beerli et al., 2004). Loyal customers are an important aspect of business. Attracting new customers cost money while retaining existing customers saves money (Gefen, 2002). A study on store loyalty and consumer spending in the United Kingdom concluded that loyal consumers constitute the most profitable segment of shoppers (Knox \& Denison, 2000). Similarly, customer loyalty assures the firm of more and guaranteed income, increased profitability and market share, decreased operational and marketing costs, increased employee morale and productivity, consumer price indifference, positive word-of-mouth communication, customer resistance to competition, cross sales, referrals and endorsements, inter alia (Lewis \& Soureli, 2006; Kandampully \& Suhartanto, 2000). Likewise, research has shown that the cost of attracting a new customer is five to six times higher than that of retaining the existing one (Wood, 2004; Mellens, Dekimpe \& Steenkamp, 1996). This makes customer loyalty the firm's strategic marketing asset which greatly contributes to brand equity (Mellens et al., 1996).

As global competition intensifies, customer loyalty has become a strategic tool for survival (Boohene \& Agyapong, 2011; Chiou, 2004). Likewise, Delgado-Ballester and Munuera-Alemán (2001) noted that, against the backdrop of increasing competition that has culminated in increased unpredictability and dwindling product differentiation, firms have placed the creation and sustenance of customer loyalty at the heart of their marketing strategy. The major thrust of marketing strategy is to develop, maintain or enhance customer loyalty towards the firm's products. This makes customer loyalty a key ingredient in the development of sustainable competitive advantage for the firm (Dick \& Basu, 1994). The increasingly importance of customer loyalty as a strategic tool in fighting competition has been motivated by the fact that customer loyalty provides a substantial barrier to the entrance of new competitors and increases the company's ability to deal with competition. Apart from generating more sales and revenue, customer loyalty creates a pool of customers who are not easily swayed by the manoeuvres of competitors (Delgado-Ballester \& Munuera-Alemán, 2001). More so, the firm's success is largely influenced by not only attracting new customers but also by retaining its existing customers and converting them into loyal consumers. Brand loyal consumers make the company more competitive than its rivals, reduce the firm's costs, are willing to pay more and are less sensitive to price than non-loyal consumers. Brand loyal consumers also give the firm some leverage and ample time to respond to moves by the firm's competitors (Lewis \& Soureli, 2006; Delgado-Ballester \& Munuera-Alemán, 2001; Knox \& Denison, 2000; Rossat et al., 1999; Mellens et al., 1996).

Loyal customers engage in repeat purchasing, leading to increased sales volume and firm profits. They constitute the bedrock for the success of any business (Caruana, 2002). A loyal customer is viewed by Kandampully and Suhartanto (2000) as the one who repurchases from the same service provider whenever possible, and who continues to recommend or maintains a positive attitude towards the service provider. Similarly, consumer loyalty has associated outcomes-referred to as loyalty outcomes-in the form of recommendation to other consumers, decreased search for alternative offerings and increased customer retention (East et al., 2005). Apart from recommending the firm's offerings to other customers, loyal customers are prepared to pay premiums for the company's products (Lewis \& Soureli, 2006; Delgado-Ballester \& Munuera-Alemán, 2001; Knox \& Denison, 2000; Rossat et al., 1999).

\subsection{Measuring customer loyalty}

Customer loyalty is a complex concept whose dimensionality has been a subject of debate (Lewis \& Soureli, 2006; Yu \& Dean, 2001). Similarly, Söderlund (2006) observes that although customer loyalty has increasingly received much attention in the field of marketing, its measurement using multi-items has generated a lot of confusion.

Most loyalty definitions are based on repeat purchasing. The problem with this approach is that it only captures what the consumer does and ignores the psychological meaning of loyalty (Oliver, 1999). In their seminal work to demystify the dimensionality of customer loyalty, Dick and Basu (1994) proposed that customer loyalty consists of two components, namely behavioural and attitudinal. Cross-classification of loyalty based on attitude and behaviour led to the four levels of loyalty called true (high) loyalty, latent loyalty, spurious loyalty and low (no) loyalty as already explained. The same stance is taken by Lewis and Soureli (2006) and East et al. (2005) who argue that a combination of attitude and behaviour has resulted in better measures of consumer loyalty. Thus, two-dimensional measurements of loyalty provide more accurate results (Assael, 2004; Yang \& Peterson, 2004; Yi \& Jeon, 2003). Moreover, Baloglu (2002:47) 
argues that "marketers who are interested in determining whether their frequent guests are truly loyal must assess both their guests' attitudes and their actions". Likewise, repeat purchase is not a sufficient measure of true loyalty. Customers may continue to purchase products due to other reasons that may exclude their attitudinal commitment to the brand or company (Assael, 2004; Garland \& Gendall, 2004). The behavioural component is concerned with the behaviour of the customer on repeat purchases. It denotes brand or product preference over time. The attitudinal component explains the customer's intention to purchase again and to recommend the product to others (Kandampully \& Suhartanto, 2000). Baloglu (2002) justifies the need for a two-dimensional approach to the measurement of customer loyalty. Concentrating on behaviour alone does not help much as it does not explain why customers are purchasing repeatedly. On the other hand, focusing on attitude alone does not explain situational factors, brand familiarity and effects of competition i.e. where there is shared loyalty or multi-brand loyalty. It is also helpful for marketers to consider the two-dimensional approach to loyalty as it makes it easier to identify loyalty segments. This would ensure that loyalty building strategies can be attuned for each segment. Schiffman and Kanuk (2004) agree to this view and suggest that behavioural definitions-such as frequency of purchase or proportion of total purchases-of consumer loyalty lack precision because they do not distinguish between the 'real' brand loyal buyer who is intentionally faithful and the spurious brand loyal consumer who repeats a brand purchase simply because it is the only one available at the store.

\section{Research Methodology}

\subsection{Questionnaire design}

The design of the questionnaire was based on the two dimensions of customer loyalty, namely attitude and repeat purchase behaviour (Lewis \& Soureli, 2006; East et al., 2005; Assael, 2004; Garland \& Gendall, 2004; Yang \& Peterson, 2004; Yi \& Jeon, 2003; Baloglu, 2002; Kandampully \& Suhartanto, 2000; Oliver, 1999; Dick \& Basu, 1994). A total of ten items -five items each for the attitudinal and behavioural components-were used to measure customer loyalty based on the work of Lewis and Soureli (2006), Söderlund (2006), Bruner II, Hensel and James (2005), Beerli et al. (2004), Schiffman and Kanuk (2004), Baloglu (2002), East et al. (2000) and Kandampully and Suhartanto (2000). Table 1 illustrates the items used to measure customer loyalty and the associated item codes.

Table 1. Items used to measure customer loyalty

\begin{tabular}{lc}
\hline Item & Code \\
\hline Imported poultry meat products taste good. & ATL1 \\
Imported poultry meat products are appealing. & ATL2 \\
Imported poultry meat products are excellent. & ATL3 \\
Imported poultry meat products are favourable. & ATL4 \\
Imported poultry meat products are preferred most. & ATL5 \\
I am willing to buy imported poultry meat products again. & RP1 \\
I always buy imported poultry meat products. & RP2 \\
I often buy imported poultry meat products. & RP3 \\
I repeatedly spend more on imported poultry meat products than local products. & RP4 \\
I always try to persuade others also to buy imported poultry meat products. & RP5 \\
\hline
\end{tabular}

Source: Adapted from Lewis and Soureli (2006); Söderlund (2006); Bruner II et al. (2005); Beerli et al. (2004); Schiffman and Kanuk (2004); Baloglu (2002); East et al. (2000); Kandampully and Suhartanto (2000).

Respondents were asked to rate the statements in Table 1 based on a 7-point Likert scale that ranged from 1 'strongly disagree' to 7 'strong agree'.

\subsection{Sampling and data collection procedures}

A cross-section of 400 consumers was taken in Harare and Bulawayo, the two major cities in Zimbabwe. The questionnaire was interviewer-administered. Consumers were randomly intercepted while shopping in the major shopping malls. Although it was relatively expensive, this technique was chosen because it ensured a relatively high response rate. As such, out of the 400 questionnaires, 305 were completed and usable, giving a response rate of $76.25 \%$. Saunders, Lewis and Thornhill (2009) suggest that a response rate of between 50 and $70 \%$ is acceptable when using interviewer- 
administered questionnaires.

\subsection{Data analysis procedures}

The initial stage was to clean data. After coding and entering data into SPSS 21, exploratory factor analysis (EFA) was performed to validate the dimensionality of customer loyalty. Confirmatory factor analysis (CFA) was then performed in AMOS 21 to test for the significance of the components making up the construct of customer loyalty.

\section{Results}

\subsection{Sample profile}

Out of 305 respondents, there were 139 males and 166 females. The distribution of the sample by age was as follows: there were four respondents aged between 18 and 19 years, 56 respondents between 20 and 24 years, 80 respondents between 25 and 29 years, 93 respondents between 30 and 39 years, 61 respondents between 40 and 49 years while 11 respondents were aged between 50 and 59 years. The distribution of the respondents in terms of highest level of education achieved was as follows: - there was one respondent who had attained Grade 7 while 18 respondents had attained the Zimbabwe Junior Certificate level. Twenty one (21) respondents were educated up to the Ordinary level while 33 had attained an Advanced level of education. Ninety eight (98) respondents had attained a Diploma, 102 had attained a Bachelor's Degree while 32 had attained a Post-graduate qualification.

\subsection{Exploratory factor analysis}

The dimensions of the construct of customer loyalty were validated by EFA in SPSS 21. Initially, the sample was checked for adequacy and whether or not data permitted factor analysis. The Kaiser-Meyer-Olkin Measure of Sampling Adequacy (KMO) was used to check for the adequacy of the sample while the Bartlett's Test of Sphericity was used to check whether or not data permitted factor analysis. The KMO statistic was found to be 0.889 . The Bartlett's Test of Sphericity was significant at $p<0.001$ with an approximate Chi-square of 1461.576 and degrees of freedom (DF) of 45 . These findings suggest that the sample was adequate and permitted factor analysis. This follows the recommendations by Field (2005) that the KMO statistic should be at least 0.5 while the Bartlett's Test of Sphericity should be significant at $p<0.05$. EFA results are presented in Table 2.

Table 2. Results of exploratory factor analysis

\begin{tabular}{|c|c|c|c|c|c|c|}
\hline Factor & Item Mean & $\begin{array}{l}\text { Standard } \\
\text { deviation }\end{array}$ & $\begin{array}{l}\text { Factor } \\
\text { loading }\end{array}$ & $\begin{array}{l}\text { Item-total } \\
\text { correlation }\end{array}$ & $\begin{array}{c}\% \text { Variance } \\
\text { explained }\end{array}$ & $\begin{array}{c}\text { Reliability } \\
\text { analysis } \\
\text { (Cronbach's } \alpha \text { ) }\end{array}$ \\
\hline \multirow{5}{*}{$\begin{array}{l}\text { Repeat purchase } \\
\text { loyalty }\end{array}$} & RP2 2.15 & 1.508 & 0.875 & 0.796 & \multirow[t]{5}{*}{$49.346 \%$} & \multirow[t]{5}{*}{0.885} \\
\hline & RP4 2.06 & 1.541 & 0.866 & 0.752 & & \\
\hline & RP3 2.03 & 1.472 & 0.829 & 0.721 & & \\
\hline & RP5 2.06 & 1.518 & 0.778 & 0.643 & & \\
\hline & RP1 2.39 & 1.673 & 0.868 & 0.709 & & \\
\hline \multirow{5}{*}{ Attitudinal loyalty } & ATL2 3.58 & 2.044 & 0.788 & 0.473 & \multirow[t]{5}{*}{$14.495 \%$} & \multirow[t]{5}{*}{0.795} \\
\hline & ATL4 2.69 & 1.630 & 0.735 & 0.680 & & \\
\hline & ATL5 3.04 & 1.911 & 0.727 & 0.551 & & \\
\hline & ATL1 2.42 & 1.408 & 0.686 & 0.651 & & \\
\hline & ATL3 2.26 & 1.483 & 0.653 & 0.588 & & \\
\hline
\end{tabular}

Extraction Method: Principal Component Analysis.

Rotation Method: Oblimin with Kaiser Normalisation.

Rotation converged in 6 iterations.

Based on Eigenvalues $>1.00$

Total variance explained $=63.841 \%$

Loadings of less than 0.4 were suppressed 
Table 2 illustrates that two factors were extracted from the data. Five items, namely RP2, RP4, RP3, RP5 and RP1 loaded on the first factor. As expected, these items explained the repeat purchase behaviour of consumers towards imported poultry meat products; hence the factor was named repeat purchase loyalty. The other five items, namely ATL2, ATL4, ATL5, ATL1 and ATL3 loaded on the second factor. As expected, these items described the attitude of consumers toward imported poultry meat products; hence the factor was named attitudinal loyalty. These two factors were measured reliably as indicated by the Cronbach's a of 0.885 and 0.795 for repeat purchase and attitudinal loyalty respectively (Zikmund, Babin, Carr \& Griffin, 2010; Bryman, 2008).

\subsection{Confirmatory factor analysis}

CFA was executed in AMOS 21 to determine the significance of the two factors (dimensions of customer loyalty) extracted from the data through EFA. The measurement model proposed was executed in AMOS 21. The results are presented in Table 3 and Figure 2.

As illustrated in Table 3, the measurement model fit indices are acceptable $(X 2=61.663, \mathrm{DF}=32, \mathrm{CMIN} / \mathrm{DF}=$ 1.927; $\mathrm{GFI}=0.962 ; \mathrm{AGFI}=0.935 ; \mathrm{NFI}=0.958 ; \mathrm{TLI}=0.971 ; \mathrm{RMSEA}=0.055)$. According to Hooper, Coughlan and Mullen (2008) and Reisinger and Mavondo (2007), CMIN/DF should be less than 3 while GFI, AGFI, NFI and TLI should be close to 1. Hooper et al. (2008) also recommend that RMSEA should range between 0.05 and 0.1 .

Table 3. Model Fit Indices

\begin{tabular}{lc}
\hline Measurement & Index \\
\hline Sample size & 305 \\
Chi-square (X2) & 61.663 \\
Degrees of freedom (DF) & 32 \\
CMIN/DF & 1.927 \\
Goodness of fit index (GFI) & 0.962 \\
Adjusted GFI (AGFI) & 0.935 \\
Normed Fit Index (NFI) & 0.958 \\
Tucker-Lewis Index (TLI) & 0.971 \\
Root mean square error of approximation (RMSEA) & 0.055 \\
\hline
\end{tabular}

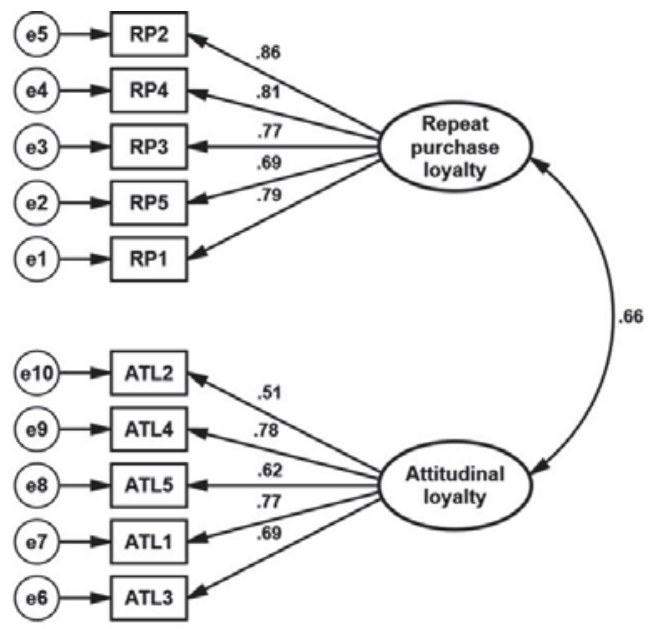

Figure 2. Measurement model

As shown in Figure 2, all items loaded sufficiently (loadings ranged between 0.51 and 0.86 ) onto their respective dimensions of customer loyalty. All item loadings were significant at $p<0.001$. Field (2005) recommends that loadings greater than 0.4 are substantive. The critical ratios for each item loading were significant $(p<0.001)$ and sufficiently large (ranged between 7.926 and 16.471). The standardised estimate for the correlation between repeat purchase and attitudinal loyalty was 0.66 and significant at $p<0.001$ with a critical ratio of 7.581 . This indicates convergence validity and suggests that although repeat purchase and attitudinal loyalty are related, Zimbabwean consumers still regard them 
as different.

\section{Discussion and Implications}

Despite customer loyalty being given considerable attention in marketing, its measurement, especially using multi-item scales, has created a lot of debate (Lewis \& Soureli, 2006; Söderlund, 2006). This has led some scholars to conclude that the construct of customer loyalty is a complex one (Yu \& Dean, 2001) while others allude that to the fact that the construct remains relatively unexplored (McMullan \& Gilmore, 2003). In the scarcity of empirical evidence to determine the reliability and validity of the attitudinal and behavioural typology of loyalty, the present study was conducted to fill this knowledge gap. The purpose of the study was, therefore, to assess the reliability and validity of the attitudinal and behavioural typology of customer loyalty towards imported poultry meat products in Zimbabwe, a developing country.

The study found that the attitudinal and behavioural (repeat purchase) typology is a reliable and valid measure of customer loyalty. This implies that in developing countries such as Zimbabwe, the two-dimensional approach to measuring customer loyalty is also applicable. The findings concur with the growing body of customer loyalty knowledge that advocates for the consideration of both attitude and behaviour when measuring customer loyalty (Assael, 2004; Garland \& Gendall, 2004). This extends the criticism levelled against the one-dimensional approach to the measurement of customer loyalty. For example, Oliver (1999) argues that considering the behavioural aspect alone only captures what the consumer does and ignores the psychological meaning of loyalty. The seminal work in the development of the construct of customer loyalty proposed that this construct consists of attitudinal and behavioural (repeat patronage) components (Dick \& Basu, 1994). Many scholars also weigh in to support this view (Assael, 2004; Yi \& Jeon, 2003; Yang \& Peterson, 2004). Similarly, Lewis and Soureli (2006) and East et al. (2005) submit that a combination of attitude and behaviour has resulted in better measures of consumer loyalty.

Marketing practitioners and researchers in developing countries are recommended to consider both the attitudinal and behavioural (repeat purchase) components when planning customer loyalty programmes and conducting consumer research. In view of this recommendation, Baloglu (2002:47) suggests that "marketers who are interested in determining whether their frequent guests are truly loyal must assess both their guests' attitudes and their actions". This implies that customers may continue to purchase products or frequently patronise a service provider due to some reasons not related to their emotions. For example, consumers may find it convenient to do so, they may not have sufficient time and alternatives may not be available. Repeat purchase behaviour is thus not sustainable. As conditions become conducive for the customers-when alternatives are available and when consumers have ample time to shop around-they may not continue to purchase the firm's products or re-patronise the service provider. Thus, both attitudinal and behavioural components are important aspects of customer loyalty. The behavioural component is a manifestation of the attitudinal component while the attitudinal component is an explanation of the reasons why customers engage in repeat purchase or repeat patronage. Since these two dimensions are correlates, they reinforce each other.

\section{Limitations and Recommendations for Future Research}

This study is not immune to limitations. It remains one of the pioneers in the assessment of reliability and validity of the attitudinal and behavioural typology of customer loyalty in developing countries. It is, thus, recommended that further studies be conducted in other developing countries to validate the present findings. More so, only one product category was considered hence, it may be worthwhile to assess the reliability and validity of the two-dimensional typology of customer loyalty toward other product categories.

\section{References}

Assael, H. (2004). Consumer behaviour: A strategic approach, Boston: Houghton Mifflin Company.

Baloglu, S. (2002). Dimensions of customer loyalty: Separating friends from well wishers. Cornell Hotel and Restaurant Administration Quarterly, 43(1), 47-59.

Beerli, A, Martín, J.D, \& Quintana, A. (2004). A model of customer loyalty in the retail banking market. European Journal of Marketing, 38(1/2), 253-275.

Boohene, R, \& Agyapong, G.K.Q. (2011). Analysis of the Antecedents of Customer Loyalty of Telecommunication Industry in Ghana: The Case of Vodafone (Ghana). International Business Research, 4(1), 229-240.

Bruner II, G.C, Hensel, P.J, \& James, K.E. (2005). Marketing scales handbook, Volume IV: A combination of multi-item measures for consumer behaviour and advertising, Ohio, USA: Thompson Higher Education.

Bryman, A. (2008). Social research methods, 3rd ed. New York: Oxford University Press Inc. 
Caruana, A. (2002). Service loyalty: The effects of service quality and the mediating role of customer satisfaction. European Journal of Marketing, 36(7), 811-828.

Chiou, J. S. (2004). The antecedents of consumers' loyalty toward Internet service providers. Information \& Management, 41(2004), 685695.

Delgado-Ballester, E, \& Munuera-Alemán, J.L. (2001). Brand trust in the context of consumer loyalty. European Journal of Marketing, 35(11/12), 1238-1258.

Dick, A.S, \& Basu, K. (1994). Customer loyalty: Toward an Integrated Conceptual Framework. Journal of the Academy of Marketing Science, 22(2), 99-113.

Douglas, S.P, \& Nijssen, E.J. (2003). On the use of "borrowed" scales in cross-national research. International Marketing Review, 20(6), 621-642.

East, R, Gendall, P, Hammond, K, \& Lomax, W. (2005). Consumer Loyalty: Singular, Additive or Interactive? Australasian Marketing Journal, 13(2), 10-26.

East, R, Sinclair, J, \& Gendall, P. (2000). Loyalty: Definition and Explanation. ANZMAC 2000 Visionary Marketing for the 21st Century: Facing the Challenge, 286-290.

Field, A. (2005). Discovering statistics using SPSS, $2^{\text {nd }}$ ed. London: SAGE Publications.

Garland, R, \& Gendall, P. (2004). Testing Dick and Basu's Customer Loyalty Model. Australasian Marketing Journal, $12(3), 81-87$.

Gefen, D. (2002). Customer Loyalty in E-Commerce. Journal of the Association for Information Systems, 3(1), $27-51$.

Hooper, D, Coughlan, J, \& Mullen, M. (2008). Structural Equation Modelling: Guidelines for Determining Model Fit. Electronic Journal of Business Research Methods, 6(1), 53-60.

Irvine's. (2012). Zimbabwe Poultry Association. Chicken Talk: Irvine's Official In-House Magazine, 19, 1-25.

Kandampully, J, \& Suhartanto, D. (2000). Customer loyalty in the hotel industry: the role of customer satisfaction and image. International Journal of Contemporary Hospitality Management, 12(6), 346-351.

Knox, S.D, \& Denison, T.J. (2000). Store loyalty: its impact on retail revenue. An empirical study of purchasing behaviour in the UK. Journal of Retailing and Consumer Services, 7(1), 33-45.

Kotler, P., Keller, K. L., Brady, M., Goodman, M., \& Hansen, T. (2009). Marketing management, Essex, England: Pearson Education Limited.

Lewis, B. R., \& Soureli, M. (2006). The antecedents of consumer loyalty in retail banking. Journal of Consumer Behaviour, 5(2006), 1531.

McMullan, R, \& Gilmore, A. (2003). The conceptual development of customer loyalty measurement: A proposed scale. Journal of Targeting, Measurement and Analysis for Marketing, 11(3), 230-243.

Mellens, M, Dekimpe, M.G, \& Steenkamp, J-B.E.M. (1996). A Review of Brand-Loyalty Measures in Marketing. Tijdschrift voor Econoniie en Management, XLI(4), 507-533.

Oliver, R.L. (1999). Whence Consumer Loyalty? The Journal of Marketing, 63(Fundamental Issues and Directions for Marketing), $33-44$.

Pentz, C, Terblanche, N.S, \& Boshoff, C. (2013). Measuring Consumer Ethnocentrism in a Developing Context: An Assessment of the Reliability, Validity and Dimensionality of the CETSCALE. Journal of Transnational Management, 18(13), 204-218.

Ranjbarian, B., Rojuee, M., \& Mirzaei, A. (2010). Consumer ethnocentrism and buying intentions: An Empirical Analysis of Iranian Consumers. European Journal of Social Sciences, 13(3), 371-386.

Reisinger, Y, \& Mavondo, F. (2007). Structural Equation Modelling. Journal of Travel \& Tourism Marketing, 21(4), 41-71.

Rossat, J, Larsen, J, Ruta, D, \& Wawrzynosek, M. (1999). Customer Loyalty, a literature review and analysis. Working Group Marketing Strategies \& Consumer Policy, 1-26.

Saffu, K., \& Walker, J. (2006). An assessment of the CETSCALE in a developing country. Journal of African Business, 7(1-2), 167-181.

Saunders, M., Lewis, P., \& Thornhill, A. (2009). Research methods for business, $5^{\text {th }}$ ed. London: Prentice Hall.

Schiffman, L. G., \& Kanuk, L. L. (2004). Consumer behaviour, $8^{\text {th }}$ ed. Upper Saddle River, New Jersey: Pearson Prentice Hall.

Söderlund, M. (2006). Measuring customer loyalty with multi-item scales. A case for caution. International Journal of Service Industry Management, 17(1), 76-98.

Teo, P.C., Mohamad, O., \& Ramayah, T. (2011). Testing the dimensionality of consumer ethnocentrism scale (CETSCALE) among a young Malaysian consumer market segment. African Journal of Business Management, 5(7), 2205-2816.

Wood, L.M. (2004). Dimensions of brand purchasing behaviour: Consumers in the 18-24 age group. Journal of Consumer Behaviour, 4(1), 9-24.

Yang, Z, \& Peterson, R.T. (2004). Customer Perceived Value, Satisfaction, and Loyalty: The Role of Switching Costs. Psychology \& Marketing, 21(10), 799-822.

Yi, Y, \& Jeon, H. (2003). Effects of Loyalty Programs on Value Perception, Program Loyalty, and Brand Loyalty. Journal of the Academy of Marketing Science, 31(3), 229-240.

Yu, Y-T, \& Dean, A. (2001). The contribution of emotional satisfaction to consumer loyalty. International Journal of Service Industry Management, 12(3), 234-250.

Zikmund, W. G., Babin, B. J., Carr, J. C., \& Griffin, M. (2010). Business research methods, 8th ed. Mason, OH: South-Western, CENGAGE Learning. 